\title{
PERFORMANCE E-GOVERNMENT UNTUK PENINGKATAN PARTISIPASI MASYARAKAT DALAM PEMBANGUNAN INFRASTRUKTUR DI KABUPATEN SIDOARJO
}

\author{
Totok Wahyu Abadi \\ Fakultas Ilmu Sosial dan Ilmu Politik \\ Universitas Muhammadiyah Sidoarjo-Jawa Timur \\ Email:totokwahyu@umsida.ac.id. \\ Nunung Prajarto \\ Fakultas Ilmu Sosial dan Politik Universitas Gadjah Mada \\ Budi Guntoro \\ Fakultas Peternakan Universitas Gadjah Mada
}

\begin{abstract}
The Innovation of website by local governments can actually be used to improve public services and encourage community participation in development.This study aims to analyze and explain (1) the performance of e-government, (2) participation in infrastructure development, and (3) the influence of the performance of e-government toward public participation in infrastructure development in Sidoarjo. The method used is explanatory approach with a sample of 233 respondents as the users of the local government of Sidoarjo. Analyzing technique used is multiple regression and path analysis. The results showed that the performance of e-government in Sidoarjo district that includes ease of use, usefulness, web interface, a complementary relationship, as well as public services is categorized as good at $68.81 \%$. Public participation in infrastructure development is regarded as medium category, which is $57.12 \%$. The most dominant community participation is information search, supervision; discussion or public consultation; partnership in the provision of funds, energy, and thought. The performance of e-government significantly influences the participation. Gender also directly affects community participation and indirectly affects participation through the use of e-government.
\end{abstract}

Keywords: Performance of e-government, Community participation, Development of infrastructure.

\begin{abstract}
ABSTRAK
Inovasi website oleh pemerintah daerah sesungguhnya dapat digunakan untuk peningkatan pelayanan publik maupun mendorong partisipasi masyarakat dalam pembangunan. Penelitian ini bertujuan untuk menganalisis dan menjelaskan (1) performance e-government, (2) partisipasi masyarakat dalam pembangunan infrastruktur, dan (3) pengaruh performance e-government terhadap partisipasi masyarakat dalam pembangunan infrastruktur di Kabupaten Sidoarjo. Metode penelitian survei ini menggunakan pendekatan eksplanatori dengan sampel sebanyak 233 responden sebagai user website pemerintah daerah Kabupaten Sidoarjo. Teknik penganalisisan yang digunakan adalah analisis Regresi Berganda dan Jalur. Hasil penelitian menyatakan bahwa performance e-government pemerintah Kabupaten Sidoarjo yang meliputi kemudahan dalam menggunakan, kemanfaatan, tampilan web, hubungan yang saling melengkapi, serta layanan masyarakat termasuk kategori baik yaitu sebesar $68,81 \%$. Partisipasi masyarakat dalam pembangunan
\end{abstract}


infrastruktur termasuk dalam kategori sedang, yakni $57,12 \%$. Partisipasi masyarakat yang paling dominan adalah pencarian informasi, pengawasan; diskusi ataupun konsultasi publik; melakukan kemitraan dalam penyediaan dana/barang, tenaga, dan pemikiran. Performance e-government berpengaruh secara signifikan terhadap partisipasi masyarakat. Jenis kelamin juga berpegaruh secara langsung terhadap partisipasi masyarakat serta secara tidak langsung berpengaruh terhadap partisipasi melalui penggunaan e-government.

Keywords: Performance e-government, partisipasi masyarakat, pembangunan infrastruktur.

\section{PENGANTAR}

Pembangunan infrastruktur memiliki peran yang sangat strategis karena terkait sekali dengan urusan pelayanan publik. Dengan tersedianya infrastruktur yang baik dan memadai, moda transportasi pun menjadi lancar dan pada akhirnya dapat meningkatkan perekonomian, kesejahteraan rakyat, mengangkat harkat, dan daya saing daerah di tingkat global.

Infrastruktur sebagai salah satu sektor pendukung transportasi umum termasuk salah satu kebutuhan masyarakat yang tinggi (Purwanto, 2008). Keniscayaan tersebut cukup beralasan karena kontribusi masyarakat terhadap layanan tersebut juga tinggi. Sementara kondisi infrastruktur di Kabupaten Sidoarjo masih ada saja yang memprihatinkan. Meski pembangunan infrastruktur transportasi berupa jalan beraspal selama kurun 20062010 mengalami peningkatan sepanjang 90,13 km, namun kondisi jalan yang rusak juga masih sepanjang $134,56 \mathrm{Km}$ dari total jalan kabupaten 917,83 Km. Jalan beraspal yang berkondisi sedang sepanjang 301,98 Km (RPJPM Kabupaten Sidoarjo 2010-2014). Agar pembangunan infrastruktur menjadi lebih baik, perlu adanya partisipasi masyarakat yang tidak hanya sebagai penerima manfaat tetapi juga sebagai citizen control.

Partisipasi masyarakat dalam pembangunan memerlukan media fasilitasi yang dapat digunakan untuk menghubungkan dengan pemerintah. Di era konvergensi teknologi komunikasi informasi, media fasilitasi yang dapat digunakan adalah website (e-government) pemerintah daerah seperti yang termaktub dalam Instruksi Presiden Nomor 3/2003 tentang Kebijakan dan Strategi Nasional Pengembangan e-Government. Sebagai media fasilitasi dialog publik antara masyarakat dan pemerintah (G2C) dalam hal pembangunan, hal terpenting yang harus dikedepankan adalah keberlanjutan (sustainability) dialog tersebut di aras elite dalam perumusan dan penentuan kebijakan yang terkait dengan pembangunan infrastruktur.

Secara teoretis hasil akhir aktivitas penggunaan e-government merujuk pada peningkatan banyak hal dalam kehidupan masyarakat. Hana (2008) menyatakan sebagai berikut: (1) transformasi e-government dapat digunakan untuk pembangunan masyarakat informasi , (2) meningkatkan iklim investasi \& kompetisi, (3) meningkatkan transparansi, akuntabilitas, dan good governance, (4) meningkatkan partisipasi masyarakat, (5) pembuatan kebijakan baru dan manajemen pengetahuan, (6) meningkatkan akses dan kualitas pelayanan publik, dan (7) efisiensi manajemen sumber.

Penggunaan e-government dalam kaitannya dengan outcome pembangunan memberikan keuntungan dalam beberapa hal di antaranya sebagai berikut: (1) mendorong pemerintah untuk menggunakan teknologi komunikasi; (2) reformasi sektor publik serta membantu dalam mobilisasi penggunaan ICT yang berfokus pada tujuan serta tantangan umum, (3) mengidentifikasi aplikasi TIK yang mendukung reformasi publik seperti e-procurement, e-inform, peningkatan manajemen sumber daya manusia, partisipasi stakeholder), (4) mengidentifikasi kesenjangan aplikasi teknologi informasi dalam pelayanan; (5) menjembatani kesenjangan antara pembuat kebijakan dengan pelaksana pembangunan dalam hal manajemen sektor publik, fasilitasi komunikasi yang efektif di antara pengelola dalam pengembangan bisnis dan teknologi.

Tentang pengembangan e-government, Instruksi Presiden Nomor 3/2003, Prawoto (2007), dan Noor (2010) mengatakan bahwa pengembangan e-government memiliki empat kategori kegiatan, yakni persiapan, pematangan, pemantapan, dan pemanfaatan. 
Tahap persiapan ditandai dengan upaya mempersiapkan sarana dan prasarana, dasar hukum, pembuatan situs di setiap organisasi, sosialisasi situs kepada stakeholder, serta sumber daya manusia dalam pelayanan berbasis e-government. Tahap kedua adalah tahap pematangan, yakni pengembangan layanan yang mencakupi kegiatan pembuatan situs informasi publik yang interaktif, pengolahan dan persiapan penyediaan konten informasi serta pelayanan, dan pembuatan antarmuka keterhubungan dengan lembaga lain.

Tahap pemantapan merupakan tahap ketiga yang ditandai dengan pengembangan komunikasi dua arah antara pengguna layanan atau warga berkaitan dengan aksesibilitas informasi publik, pembuatan situs transaksi pelayanan publik, dan pembuatan interoperabilitas aplikasi maupun data dengan lembaga lain. Terakhir adalah tahap pemanfaatan yang ditandai dengan akses layanan secara online. Tahap pemanfaatan ini juga ditandai dengan pembuatan aplikasi yang bersifat G2G, G2B, dan G2C yang terintegrasi.

Kecuali itu, performance e-government yang dikembangkan haruslah menjadi fokus pemerintah guna peningkatan kualitas pelayanan. Performance (kinerja) e-goververnment dapatlah dilihat dari kualitas pelayanan yang diberikan kepada masyarakat. Kualitas dapat didefinisikan sebagai persesuaian standar yang terus berlaku baik proses, produk, maupun sumber daya manusia. Kualitas dapat diukur melalui penelitian masyarakat sebagai konsumen mengenai persepsi tentang mutu suatu produk atau jasa.

Dalam dimensi website, Lociacono (2002) mengategorikan dimensi $e$-service quality yang dikenal sebagai website quality (webqual) dengan empat belas dimensi. Beberapa dimensi tersebut dapat diklasifikasikan menjadi lima tingkatan website, yaitu (1) kemudahan dalam penggunaan (ease of use), (2) kemanfaatan (usefulness), (3) tampilan website (entertainment), (4) hubungan yang saling melengkapi (relationship complementary), dan (5) layanan kepada pelanggan (customer services). Level pertama terdapat dua dimensi, yaitu (1) halaman web yang didesain mudah untuk dibaca dan dipahami (ease of understanding) dan (2) kemudahan dalam mengoperasikan dan pencarian informasi (intuitive operation).

Tingkatan kedua meliputi lima dimensi, yaitu (1) ketersediaan informasi yang akurat dan relevan (information quality), (2) kesesuaian informasi dengan yang dibutuhkan untuk menyelesaikan/meningkatkan tugas (meets functional fit to-task), (3) terdapat interaksi komunikasi antara konsumen dengan institusi (interactivity), (4) terdapat keamanan dalam berkomunikasi serta kerahasiaan informasi pribadi (trust), dan (5) terdapat respon atas permintaan ataupun interaksi melalui situs (response time).

Jenjang ketiga adalah tampilan website (entertainment), yaitu tampilan situs memiliki daya tarik baik dari segi tata warna, letak, tipe dan ukuran mencetak, jumlah gambar foto, grafik, dan animasi. Dimensi yang dapat digunakan untuk mengukur sebagai berikut: (1) estetika website, (2) desain situs yang kreatif dan unik, (3) memiliki daya tarik yang dapat mempengaruhi emosional user dalam menggunakan website dan terlibat secara intens (sering).

Tingkatan keempat adalah relasi yang saling melengakapi. Dimensi yang digunakan untuk mengukurnya sebagai berikut: (1) diizinkannya user untuk melakukan transaksi secara online, (2) keuntungan relatif yang diperoleh user seperti berbiaya murah dan waktu yang relatif cepat, dan (3) pencitraan di website juga memiliki kompatibel dengan pencitraan instansi pemerintah daerah di media lainnya. Terakhir adalah website yang dikelola pemerintah dapat digunakan untuk memberikan pelayanan secara baik kepada masyarakat. Indikator yang dapat digunakan untuk mengukurnya adalah terdapatnya respon terhadap pertanyaan pelanggan, komentar, dan umpan balik (customer services).

Indrajit (2005) mengatakan bahwa tujuan akhir dari evolusi e-government adalah meningkatnya partisipasi masyarakat dalam pemerintahan maupun pembangunan. Melalui e-government, publik dapat berpartisipasi dalam 1) memberikan penilaian terhadap kebijakan pemerintah yang akan diberlakukan 
atau yang telah di-institusionalisasi secara bebas dan aktif melalui fasilitas email ataupun mailing list; 2) mencari data dan informasi yang dibutuhkan untuk proses penunjang aktivitas sehari-hari dari sejumlah website yang dimiliki pemerintah, dan 3) mengikuti beragam dialog atau public hearing yang dilakukan secara online melalui internet.

Tambouris (2008) menjelaskan bahwa level partisipasi bermedia website terdiri dari lima, yaitu (1) e-informing, (2) e-consulting, (3) e-involving, (4) e-collaborating, dan (5) e-empowerment. E-informing adalah tahapan penyampaian informasi secara online dari pemerintah kepada masyarakat. Informasi tersebut dapat berupa rencana kegiatan ataupun yang terkait dengan kebijakan. Komunikasi yang terjadi pada level ini lebih bersifat satu arah. E-consulting adalah tingkatan partisipasi yang menggunakan saluran dua arah yang bersifat interaktif. Pemerintah dalam tahapan ini dapat mengonsultasikan atau mendiskusikan dengan warga atau kelompok warga terkait dengan kebijakan yang akan dirumuskan atau permasalahan pembangunan. Segala keputusan yang terkait dengan kebijakan dalam level ini masih menjadi dominasi pemerintah. E-involving adalah level partisipasi yang terjadi antara masyarakat dengan pemerintah secara dialogis. Tahapan ini, pemerintah menyampaikan rencana yang memungkinkan untuk diperbaiki dan diubah melalui forum diskusi. E-collaboration adalah level partisipasi yang terjadi dalam komunikasi dua arah yang saling menguntungkan antara pemerintah dan masyarakat. Warga dapat berpartisipasi aktif serta memiliki peran yang sama dengan pemerintah untuk melakukan kemitraan dalam mengambil keputusan. Terakhir adalah e-empowerment, yaitu tingkat partisipasi yang menempatkan keputusan akhir berada di tangan warga. Pemerintah hanya mengimplementasikan keputusan yang diambil warga masyarakat. Level e-collaboration dan e-empowerment dalam tataran partisipasi, bila disandingkan level partisipasi menurut Arnstein, termasuk dalam level partisipasi yang paling tinggi atau disebut dengan partisipasi murni.

Namun, fakta menunjukkan sebagai berikut: (1) partisipasi masyarakat masih bersifat pseudo; (2) belum optimalnya komitmen pemerintah daerah dalam menggunakan e-government sebagai media interaksi antara pemerintah dan masyarakat serta pemanfaatannya untuk meningkatkan partisipasi masyarakat dalam pembangunan yang berkelanjutan; (3) website masih dianggap sebagai alat/teknologi belaka; (4) tidak optimalnya tindak lanjut analisis jabatan terkait dengan kapasitas sumber daya manusia dalam menggunakan teknologi informasi dan komunikasi serta pelayanan publik yang berkualitas.

Dari paparan tersebut penelitian ini secara khusus bertujuan untuk mengidentifikasi dan menganalisis performance e-government di Kabupaten Sidoarjo, e-partisipasi masyarakat dalam pembangunan infrastruktur, dan pengaruh performance e-government terhadap partisipasi masyarakat dalam pembangunan infrastruktur.

Penelitian ini didesain dengan menggunakan metodesurvei. Pengumpulan datanya dilakukan dengan menggunakan kuesioner. Tujuannya adalah memperoleh informasi tentang sejumlah responden yang dianggap merepresentasikan populasi tertentu. Jenis data yang digunakan adalah data kuantitatif. Secara kuantitatif, penelitian akan menjelaskan pengaruh atau hubungan diantara variabel dengan melakukan uji hipotesis.

Penelitian ini dilakukan di Kabupaten Sidoarjo dengan total sampel sebesar 233 respoden. Responden sebagai sampel penelitian ditentukan dengan menggunakan teknik random sampling sederhana. Data penelitian dikumpulkan dengan menggunakan angket yang didistribusikan kepada masyarakat pengguna website pemerintah Kabupaten Sidoarjo. Angket disusundengan menggunakan variabel-variabel performance e-government dan partisipasi masyarakat dalam pembangunan. Indikator performance e-government meliputi: (1) kemudahan penggunaan, (2) kemanfaatan, (3) tampilan website, (4) hubungan yang saling melengkapi, dan (5) layanan kepada masyaraka. Sedangkan partisipasi masyarakat menggunakan indikator sebagai berikut: (1) pengaksesan dan penyampaian informasi, (2) pelaksanaan konsultasi, (3) komunikasi 
dialogis, (4) kolaborasi/kerjasama, maupun (5) pemberdayaan/ pengawasan terhadap pembangunan infrastruktur.

Data dalam penelitian ini menggunakan tiga teknik penganalisisan, yaitu statistik deskriptif, regresi linier berganda, dan path analysis. Sedangkan hipotesis penelitian ini sebagai berikut: (1) e-government berpengaruh secara signifikan terhadap partisipasi masyarakat dalam pembangunan infrastruktur dan (2) karakteristik masyarakat berpengaruh secara langsung terhadap e-government dan partisipasi masyarakat serta berpengaruh secara tidak langsung terhadap partisipasi melalui e-government.

\section{PEMBAHASAN}

\section{Performance E-Government Pemerintah Kabupaten Sidoarjo}

Performance e-government dalam penelitian ini adalah kualitas pengelolaan teknologi komunikasi informasi berbasis website yang digunakan untuk peningkatan kualitas pelayanan dan partisipasi masyarakat dalam pembangunan. Dalam konteks pelayanan publik, kualitas website yang dikelola oleh pemerintah dapat dilihat dari kepuasan penggunanya (masyarakat). Grafik Satu merupakan hasil poling website pemerintah Kabupaten Sidoarjo yang menunjukkan bahwa tampilan website menurut 1135 pengunjung termasuk dalam kategori sangat kurang dan yang menyatakan sangat baik sebanyak 850 pengguna. Sementara itu hasil penelitian ini menunjukkan bahwa kualitas pengelolaan website pemerintah Kabupaten Sidoarjo termasuk dalam kategori baik, yaitu 68,81\%.

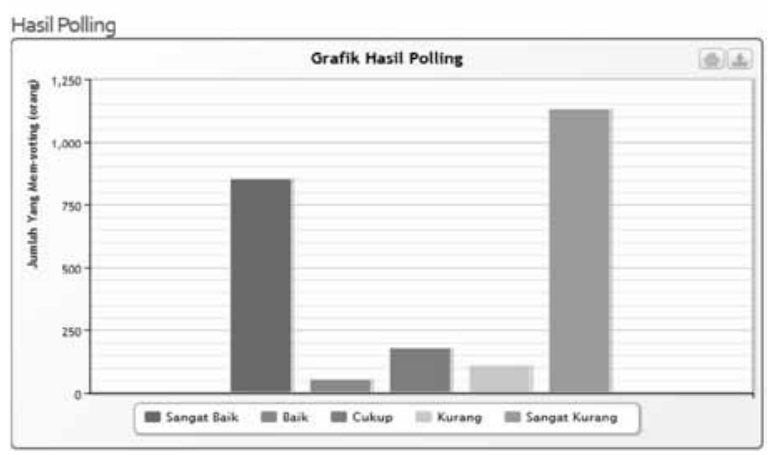

Grafik 1: Polling Tampilan Website Sumber: Website Kab.Sidoarjo, 2014
Beberapa aspek yang digunakan untuk mengamati berkualitas tidaknya website diantaranya adalah kemudahan dalam penggunaan website seperti kemudahan pembacaan dan pemahaman informasi di web, kemudahan mencari informasi, serta kecepatan dalam mendownload informasi. Kemudahan dalam penggunaan website pemerintah Sidoarjo termasuk dalam kondisi sebesar 69,40\%. Aspek kedua yaitu kemanfaatan. Kemanfaatan website bagi pengunjung dapat diperhatikan dari beberapa hal seperti keakuratan, kerelevanan, dan kesesuaian informasi yang dibutuhkan pengunjung; keamanan dalam berkomunikasi melalui website; serta terdapat terdapat tidaknya interaksi antara pemerintah dengan pengguna. Interaksi pemerintah daerah dengan masyarakat tersedia dalam domain interaktif, yaitu buku tamu dan pengaduan masyarakat (Pusat Pelayanan Informasi dan Pengaduan Masyarakat/P3M). Kualitas kemanfaatan website sebesar $68,33 \%$.

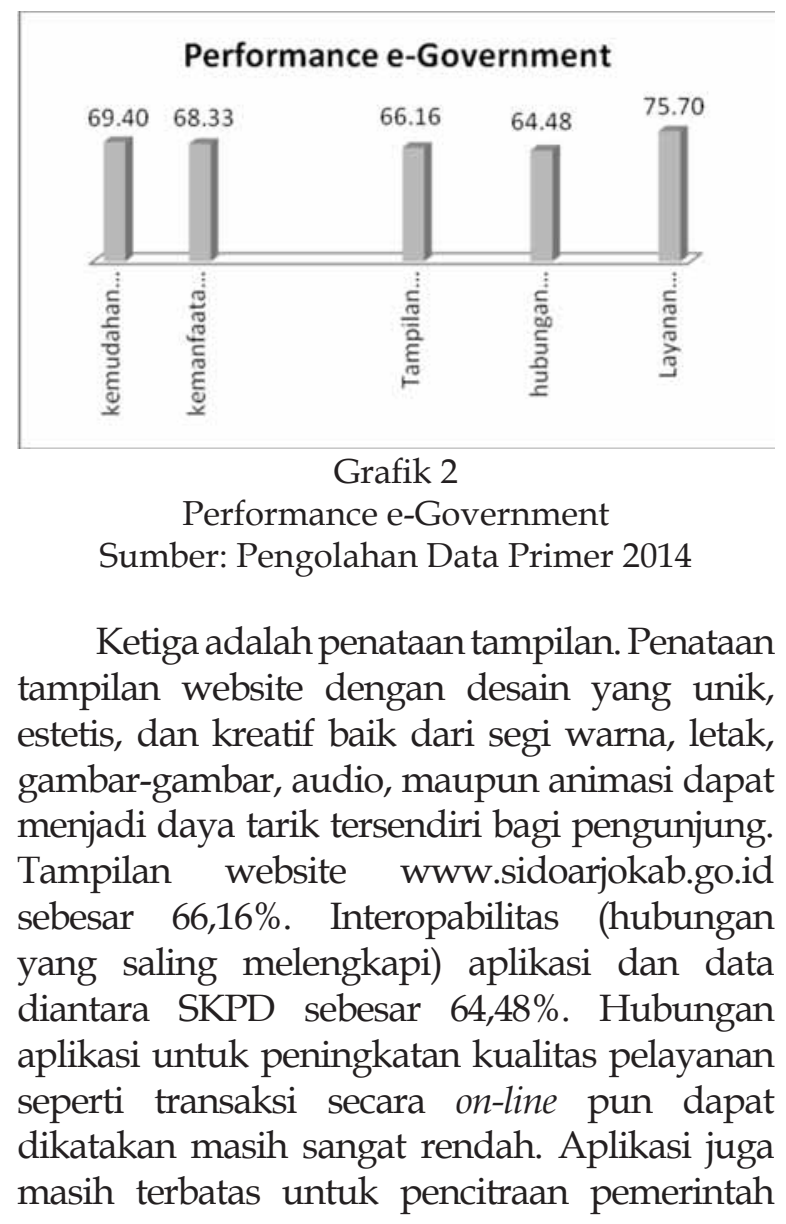


daerah melalui pemberitaan-pemberitaan yang terdisplay di halaman web. Terakhir adalah pemanfaatan web untuk pelayanan masyarakat juga menunjukkan skor sebesar 75,70\%.

Kualitas website pemerintah Kabupaten Sidoarjo yang termasuk dalam kategori baik tersebut tampaknya masih harus berbenah menjadi lebih baik sesuai dengan kebijakan nasional mengenai pelaksanaan e-government. Meski pada tahun2012 pemerintah kabupaten Sidoarjo mendapatkan penghargaan ICT Pura, pengelolaannya masih menunjukkan kekurangan, seperti yang disampaikan oleh Kasubbid Pengolahan Data Elektronik.

"sebenarnya saya sungkan kalo menceritakan kondisi pengelolaan web Pemerintah Kabupaten Sidoarjo kepada sampeyan. Sebab podo karo aku menceritakan kebobrokan pemda Sidoarjo dewe walaupun kita pernah mendapatkan ICT Pura tahun 2012. Salah satunya adalah staf yang memiliki kompetensi bidang IT dimutasi di lain bidang dan pemindahannya tidak berdasarkan analisis jabatan. Kedua, anggaran yang terlalu minim. "

(Sumber: Hasil wawancara, 2014)

Inovasi website dapat digunakan untuk mendorong dan meningkatkan partisipasi masyarakat dalam pembangunan. Partisipasi masyarakat dalam penelitian ini adalah keterlibatan seseorang atau warga dalam proses pembangunan untuk mengakses dan menyampaikan informasi ataupun kebutuhannya melalui media website. Indikator yang digunakan untuk mengukur tingkat partisipasi warga dalam proses pembangunan meliputi: (1) pengaksesan dan penyampaian informasi, (2) konsultasi; (3) dialog, (4) kemitraan, dan (5) pengawasan.

Keterlibatan warga dalam proses pembangunan melalui media website pada penelitian ini termasuk dalam kategori cukup/biasa $(57,31 \%)$. Tingkatan partisipasi yang tinggi adalah penyampaian dan permintaan informasi $(58,45 \%)$; pengawasan dan pemberian kritik kepada kebijakan pembangunanyang dilaksanakan pemerintah daerah (57,12\%). Pengawasan dan kritik sebagai bagian dari partisipasi masyarakat dalam pembangunan infrastruktur dapat diperhatikan pada kutipan mengenai kerusakan jalan umum di wilayah Sukodono Taman - Waru sejak tahun 2011 hingga saat penyampaian informasi terakhir pada 2012 melalui P3M on-line juga belum terdapat respon dan tindak lanjut dari dinas terkait.

No. Aduan
Nama
Alamat
Desa/Kelurahan
Kota
Jenis Kelamin
Telepon
Fax
Email
Pekerjaan
Tanggal Pengaduan
Tanggal Catat
Media Pengaduan
Subyek
Uraian

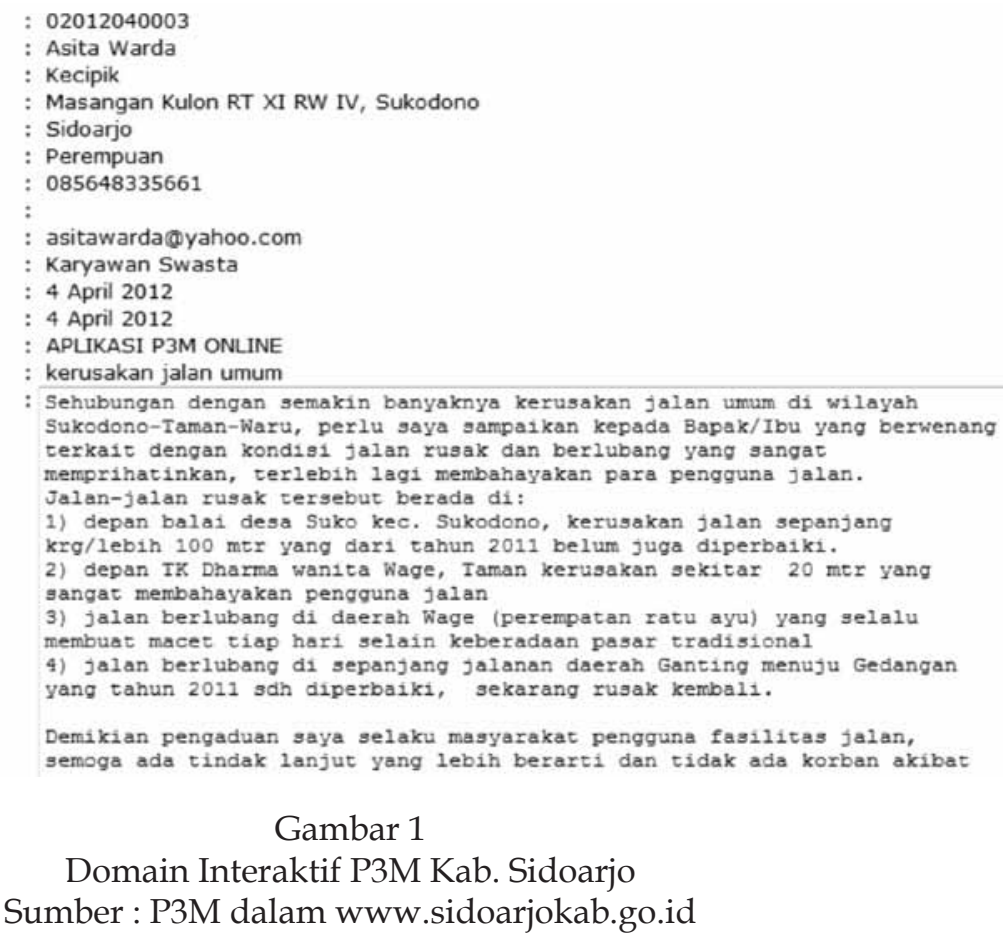


Tingkat partisipasi berikutnya adalah kemitraan masyarakat dengan pemerintah. Partisipasi masyarakat dalam bentuk kemitraan tersebut dapat dilakukan dengan cara mendedikasikan pemikiran, tenaga, serta dana kepada pemerintah daerah. Kemitraan anggota masyarakat dengan pemerintah dalam pembangunan infrastruktur telah mencapai 56,74\%. Sedangkan tingkatan partisipasi berikutnya adalah konsultasi publik $(53,31 \%)$ dan diskusi/dialog $(53,40 \%)$.

\section{Faktor-Faktor yang Mempengaruhi Partisipasi Masyarakat}

Beberapa faktor yang diduga berpengaruh terhadap partisipasi masyarakat dalam pembangunan infrastruktur diSidoarjo, yaitu karakteristik individu seperti umur, pendidikan, pekerjaan, jenis kelamin, dan performance e-government. Untuk menganalisis pengaruh tersebut, digunakan penganalisisan dengan menggunakan program SPSS 16 metode backward regression. Backward regression merupakan metode dalam program SPSS 16 yang secara otomatis menghilangkan satu per satu variabel bebas yang tidak signifikan berpengaruh. Hasil penganalisisan menunjukkan bahwa karakteristik individu dan performance e-government berpengaruh terhadap partisipasi dalam pembangunan di Kabupaten Sidoarjo. Hasil uji anova diperoleh F hitung sebesar 8,244 pada tingkat kesalahan (P) 0,000 lebih kecil dari 0,05 dengan nilai koefisien determinasi $\left(\mathrm{R}^{2}\right)$ sebesar 6,7\%. Di antara beberapa faktor yang ada terdapat dua hal yang paling berpengaruh (secara parsial) terhadap partisipasi yaitu jenis kelamin dan performance e-government. Meskipun pengaruh tersebut relatif kecil, keterpengaruhan kedua faktor tersebut dapat dinyatakan pasti.

Tabel 1

Faktor-faktor yang Mempengaruhi Partisipasi Masyarakat

\begin{tabular}{l|l|l|l|l}
\hline No & Variabel & $\begin{array}{c}\text { Koefisien } \\
\text { Regresi }\end{array}$ & T - hitung & Sig \\
\hline \multirow{2}{*}{1} & (Constant) & 43.985 & 5.344 & .000 \\
\cline { 2 - 5 } 2 & Egov & .199 & 3.127 & .002 \\
\cline { 2 - 5 } 3 & Gender & .164 & 2.568 & .011 \\
\hline
\end{tabular}

Keterangan

$\mathrm{N}: 233$

$\mathrm{R}: 0,259$

R Square: 0,067

Adjusted R Square: 0,059

F hitung: 8,244

Sig F: 0,000

Sig a: 0,05

T tabel: 2,920

Persamaan model: $Y=43,985+0,199 X 1+0,164 X 2$

Sumber: Pengolahan Data Primer 2014 dengan Metode Backward Regression

Tabel di atas menjelaskan bahwa variabel bebas seperti e-government dan gender mampu mempresentasikan partisipasi sebagai variabel terikat sebesar 6,7\%. Sedangkan sisanya 93,3\% mempresentasikan pengaruh lain yang tidak menjadi bagian dalam model. Karakteristik individu, seperti jenis kelamin, memiliki pengaruh yang kurang signifikan terhadap partisipasi seseorang dalam pembangunan. Hasil uji signifikansi menunjukkan bahwa nilai $t$ hitung $(2,568)$ lebih kecil dari $\mathrm{t}$ tabel $(2,920)$ pada taraf kesalahan sebesar 0,11 lebih kecil daripada signifikansi alfa sebesar 0,05. Meski pengaruh gender terhadap partisipasi seseorang dalam pembangunan relatif kurang signifikan, partisipasi masyarakat --- baik berjenis kelamin laki - laki maupun perempuan --- dalam pembangunan akan mengalami peningkatan sebesar $16,4 \%$ bila dikelola dan dimediasi dengan baik oleh pemerintah Kabupaten Sidoarjo. Jenis kelamin responden yang terlibat dalam partisipasi bermedia e-government rata-rata adalah laki-laki sebesar $68,9 \%$ dan perempuan sejumlah $31,1 \%$. Temuan empirik ini sejalan dengan temuan hasil penelitian Mardiantono (2003), Yulianti (2006), Setiawan (2008), serta Sandyatma dan Hariadi (2012) yang menyatakan bahwa karakteristik seseorang dapat berpengaruh terhadap partisipasi.

Pengelolaan e-government secara optimal juga dapat meningkatkan partisipasi masyarakat dalam pembangunan. Nilai koefisien regresi e-government sebesar 0,199 mengindikasikan bahwa setiap peningkatan kualitas media e-government 
dapat meningkatkan $19,9 \%$ partisipasi masyarakat dalam pembangunan. Hasil uji regresi menunjukkan bahwa performance e-government berpengaruh secara positif terhadap partisipasi masyarakat sebesar t hitung $(3,127)$ lebih besar daripada $t$ tabel $(2,920)$ dengan taraf kesalahan yakni 0,000 lebih kecil dari 0,05. Kajian empiris ini tentu sejalan dengan konsep yang disampaikan oleh Melcote (2001), Chen
(2003), Machintos (2004), Indrajit (2005), Purwanto (2006), Reitz (2006), Hana (2008), bahwa transformasi e-government mampu meningkatkan partisipasi masyarakat dalam pembangunan serta efektif dan efisien (Reitz, 2006; Soetomo, 2009) dalam menyampaikan aspirasi, saran, evaluasi, maupun kritik. Penyampaian aspirasi masyarakat sebagai bentuk partisipasi kepada pemerintah dapat diperhatikan seperti kutipan berikut:

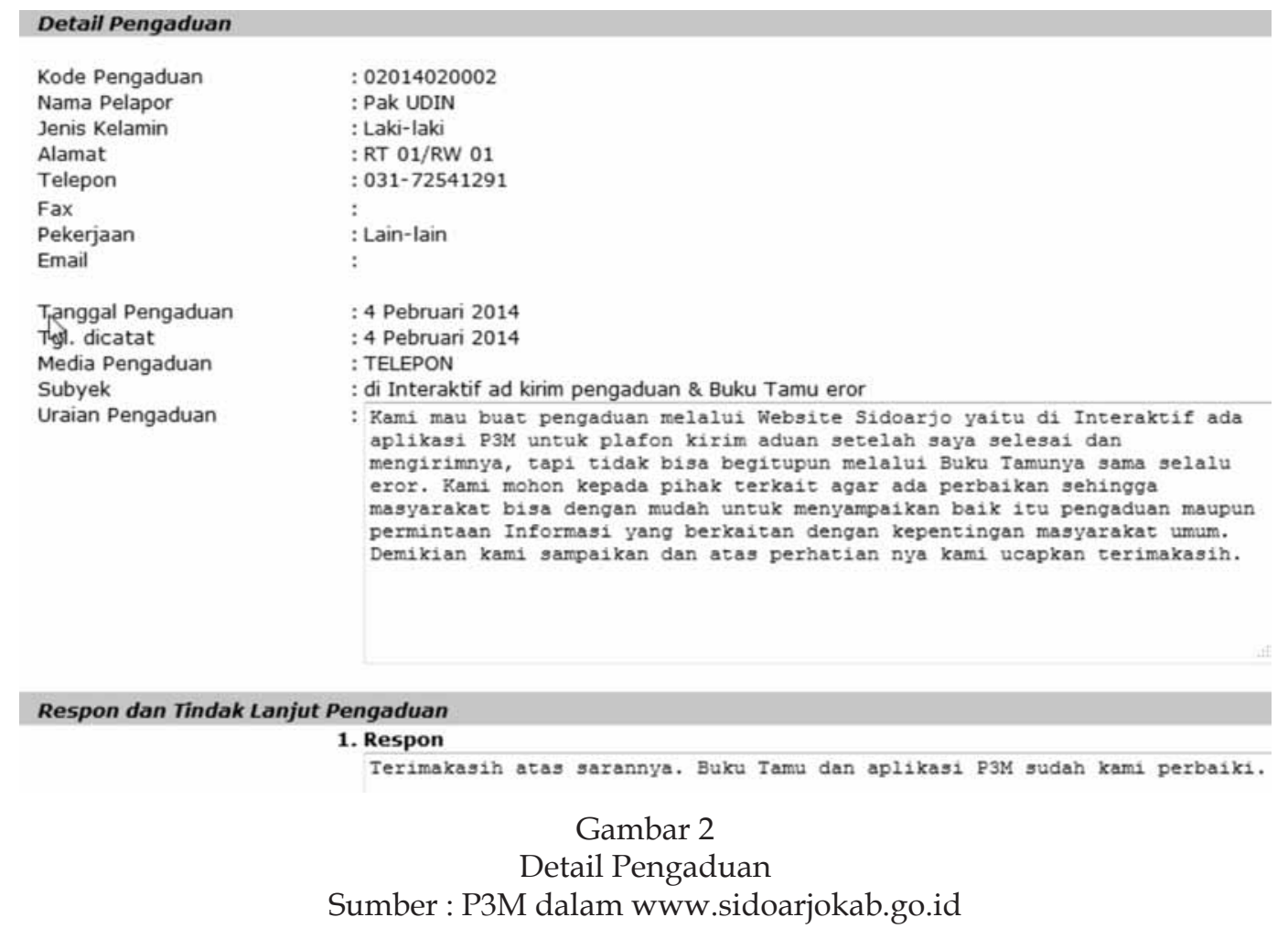

Bila disandingkan dengan level partisipasi Arnstein (Ife, 2008) yang terdiri dari delapan tangga, partisipasi yang dimediasi e-government dalam penelitian ini terdapat lima aras partisipasi. Kelima tingkatan partisipasi tersebut seperti yang dikonsepkan Tambouris (2008), yaitu e-information, e-consultation, e-involving, e-collaborating, dan e-empowering. Tangga partisipasi masyarakat berbasis e-government tersebut berada pada dimensi simbolik dan citizen power. Sementara partisipasi masyarakat sebagai pengguna dan pengerahan atau yang bersifat pseudo tidak terdapat dalam penelitian ini. Karenanya, pelayanan publik dan peningkatan partisipasi masyarakat dalam pembangunan menjadi lebih efektif dan efisien bila e-government juga mendapatkan perhatian yang serius dari pemerintah Kabupaten Sidoarjo.

\section{Hubungan Beberapa Faktor Berpengaruh terhadap Partisipasi}

Untuk menjelaskan hubungan beberapa faktor seperti karakteristik (pendidikan, usia, gender, pekerjaan) dan media e-government berpengaruh terhadap partisipasi masyarakat dalam pembangunan infrastruktur digunakan analisis jalur. Analisis jalur merupakan pengembangan dari analisis regresi. Dan dapat dikatakan bahwa analisis regresi merupakan inti dari analisis jalur. 

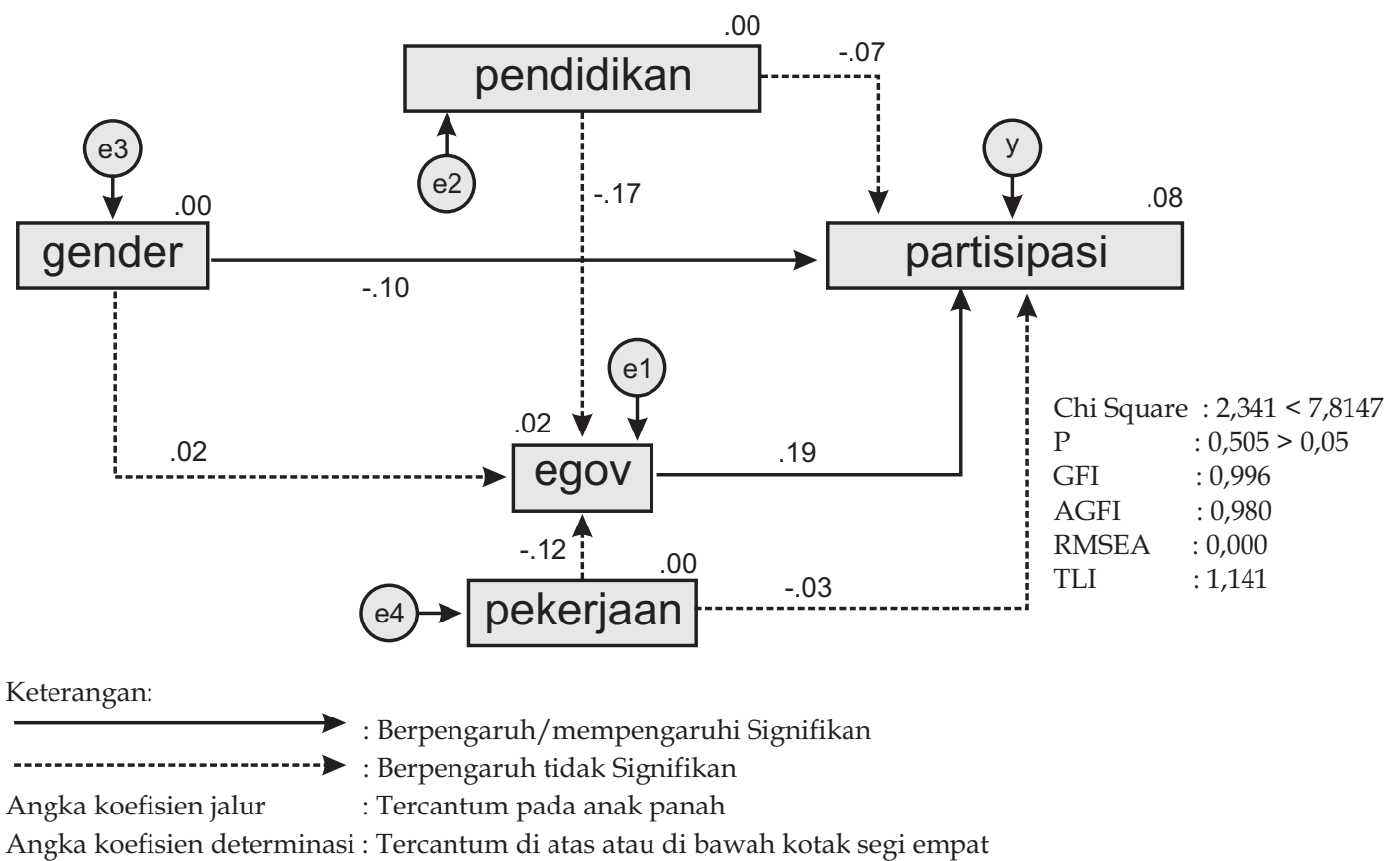

Gambar 3

Struktur Model Analisis Jalur Hubungan Antarvariabel

Sumber: Pengolahan Data Primer, 2014 dengan AMOS 20

Hasil analisis jalur berdasarkan olahan Amos 20 seperti yang tertampak dalam Gambar 1 menunjukkan bahwa variabel bebas yaitu gender dan kinerja e-government berpengaruh secara langsung terhadap partisipasi masyarakat dalam pembangunan. Sedangkan pengaruh langsung pendidikan dan pekerjaan terhadap partisipasi masyarakat tidak signifikan. Kinerja e-government memiliki pengaruh lebih besar terhadap partisipasi masyarakat daripada gender. Besarnya pengaruh kinerja e-government terhadap partisipasi masyarakat memiliki nilai koefisien jalur (regression weight) sebesar 0,19 dengan critical ratio/t hitung $(2,942)$ lebih besar dari $t$ tabel $(2,920)$ pada tingkat kesalahan 0,003 lebih kecil dari 0,05. Hal ini berarti bahwa pengaruh kinerja e-government berpengaruh secara signifikan terhadap partisipasi masyarakat dalam pembangunan. Besarnya koefisien regresi tersebut mengindikasikan bahwa setiap peningkatan kinerja e-government yang meliputi kemudahan dan kecepatan untuk mengakses informasi, kemanfaatan informasi yang didapat, tampilan website yang dikelola dengan unik dan menarik, hubungan aplikasi yang dapat dimanfaatkan untuk melakukan transaksi, serta pemanfaatan web untuk pelayanan kepada masyarakat dapat meningkatkan partisipasi masyarakat dalam pembangunan sebesar 0,19 kali.

Pengaruh langsung variabel bebas terhadap variabel bebas lainnya meliputi pengaruh pendidikan terhadap e-government sebesar - 0,10; pengaruh gender terhadap e-government sebesar 0,02; dan pengaruh pekerjaan terhadap e-government sebesar $-0,12$. Variabel bebas tersebut yang mempunyai pengaruh besar terhadap variabel bebas lainnya adalah gender meskipun pengaruh tersebut tidak signifikan dengan crtitical ratio/t hitung $(2,666)$ lebih kecil dari $\mathrm{t}$ tabel $(2,920)$ dengan tingkat kesalahan 0,008 lebih kecil dari 0,05.

Selain partisipasi masyarakat dalam pembangunan infrastruktur dipengaruhi oleh gender dan kinerja e-government, partisipasi juga dipengaruhi secara tidak langsung oleh gender, pendidikan, dan pekerjaan melalui kinerja e-government dengan total masing - masing sebesar 0,172; -0,091, dan -0,055. 
Meskipun faktor pendidikan dan pekerjaan berbanding terbalik (tanda minus) dalam mempengaruhi partisipasi dan performance e-government, hal tersebut menunjukkan bahwa selain peningkatan kualitas pembangunan infrastruktur sebagai bagian dari pelayanan publik menjadi lebih baik, pemerintah Sidoarjo harus memperhatikan karakteristik masyarakat seperti pendidikan dan pekerjaan. Melalui pendidikan, masyarakat menjadi melek pengetahuan dan teknologi komunikasi informasi serta mampu bekerja dan berpartisipasi dalam pembangunan infrastruktur secara lebih baik. Hal senada juga dikonsepsikan oleh Soetomo (2009) bahwa pendidikan akan menambah pengetahuan yang secara langsung dan tidak langsung dapat mempengaruhi kemampuan tentang cara dan teknik dalam melaksanakan pekerjaan.

Hal terpenting dalam performance e-government yang dapat mendorong peran serta masyarakat dalam pembangunan yaitu adanya respon, koordinasi, dan tindak lanjut dari Satuan Kerja Perangkat Daerah (SKPD) terkait yang terintegrasi (government to governenment/G2G). Hambatan yang selama ini terjadi dan sering muncul adalah 1) jaringan on-line yang sering rusak, 2) mutasi jabatan terhadap staf yang memiliki komptensi bidang IT pemegang kode user dan password, 3) lambatnya respon terkait dengan permintaan dan peyampaian informasi dari masyarakatkeSKPD, dan 4) lamanya disposisi respon yang diberikan pimpinan. Kecuali itu, lemahnya koordinasi selalu menjadi jargon utama yang menjadi penghambat. Hal sama juga disampaikan informan dari P3M bahwa penghambat pelayanan prima berbasis website oleh pemerintah adalah lemahnya koordinasi antar-SKPD khususnya di Bagian Telekomunikasi dan Informatika (sumber: hasil wawancara dengan Agung Wareh, 2011).

\section{SIMPULAN}

Implementasi Instruksi Presiden Nomor 3/2003 Tentang Kebijakan dan Strategi Nasional Pengembangan e-Government guna mendukung dan meningkatkan pelayanan publik serta partisipasi masyarakat masih belum berjalan secara optimal. Hal tersebut ditandai dengan hasil temuan penelitian yang menunjukkan bahwa performance e-government masih dalam kategori biasa/ sedang, baik dari aspek kemudahan dalam penggunaan, kemanfaatan, tampilan website, interopabilitasnya, maupun layanan masyarakat. Begitu halnya dengan peran serta masyarakat dalam pembangunan yang dimediasi e-government menunjukkan kualitas yang terkategorikan sedang $(57,12 \%)$. Kualitas partisipasimasyarakattersebutdapat diamati dari pencarian dan penyampaian informasi melalui web, konsultasi, dialog, kemitraan, dan pengawasan yang dilakukan oleh masyarakat kepada pemerintah daerah.

Kajian empiris juga menunjukkan bahwa performance e-government memiliki pengaruh yang positif terhadap partisipasi masyarakat dalam pembangunan. Begitu halnya dengan karakteristik masyarakat seperti pendidikan, jenis kelamin, dan pekerjaan juga berpengaruh terhadap performance e-government dan partisipasi masyarakat meskipun tidak terlalu signifikan. Karakteristik masyarakat yang ada, gender adalah faktor yang berpengaruh secara positif terhadap kinerja e-government dan partisipasi. Meski pengaruh performance e-government terhadap partisipasi masyarakat dalam pembangunan relatif kecil, faktor - faktor seperti koordinasi yang lemah diantara SKPD, sumber daya manusia, prasarana teknologi informasi, kapasitas, struktur organisasi, dan budaya birokrasi juga menjadi penghambat kinerja e-government dan partisipasi.

\section{DAFTAR PUSTAKA}

Abadi, Totok Wahyu. 2014. Performance e-Government untuk Peningkatan Partisipasi Masyarakat dalam Pembangunan Infrastruktur di Sidoarjo. Penelitian Dikti.

Bappenas, 2008. Infrastruktur dan Pembangunan Daerah: Membantu Pengurangan Kemiskinan. Jakarta.

Chen, Yu-Che James Perry.. 2003. “Outsourcing for E-Govemment: Managing 
for Success" dalam Public Performance E Management Review. Vol. 26, No.4 (June, 2003).pp.404-421. Published by: ME. Sharpe, Inc.Stable. URL:: http:// www.jstor.org/stable/3381115. Accessed: 24/05/2010 01:38:

Depkominfo. Rencana Strategis Departemen Komunikasi dan Informatika 20042009. www.depkominfo.go.id/?pid renstra\&cid. Diakses 23 February 2007.

Hanna, Nagy K. 2010Transforming Government and Building the Information Society: Challenges and Opportunities for the Developing World. Springer New York: University of Maryland.

Ife, Jim dan Frank Tesoriero 2008. Community Development: Alternatif Pengembangan Masyarakat di Era Globalisasi. Yogjakarta: Pustaka Pelajar. Hal: 285-327

Indrajit, Richardus Eko, dkk. 2005. E-Government in Action. Yogjakarta: Penerbit Audi. Hal: 27-28

Instruksi Presiden Nomor 3 Tahun 2003 Tentang Kebijakan dan Strategi Nasional Pengembangan e-Government. www.bappenas.go.id. Diunduh 7 November 2008.

Loiacono, Eleanor T; Richard T. Watson; dan Dale L. Goodhue. 2002. "Webqual: a Measure of Website Quality." Dalam Kenneth R Evans (eds). Marketing Theory and Applications. American Marketing Association/Winter. Vol. 13; Page: 432-438.

Macintosh, Ann. 2004. "Characterizing E-Participation in Policy-Making." Proceedings of the 37th Hawaii International Conference on System Sciences. Dalam http://www. jstor.org/stable/3381113. diunduh 21 Februari 2010.

Mardiantono, Toni 2003. "Identifikasi Partisipasi Masyarakat dalam Pembangunan Jalan dan Saluran Lingkungan Permukiman Kumuh di Kota Semarang." Tesis. Semarang: Undip.
Neuman, W. Lawrance. 2006. Social Research Methods: Quantitative and Qualitative Approaches. Sydney: Pearson.

Noor, Burharnuddin. 2010. “Pelayanan Publik Berbasis E-Government: Studi Kasus Pengaduan Online, PSB Online, E-Procurement di Kota Banjarbaru Kalimantan." Disertasi. Malang: Universitas Brawijaya. Tidak diterbitkan.

Parasuraman, A \& Valerie A, Zeithami; and Arvid Malhotra. 2002. "Service Quality Delivery Through Website: a Critical Review of Extant Knowladge". Journal of The Academy of Marketing Science. Vol. 30 (4), page 362-375

Parasuraman, A \& Valerie A, Zeithami; and Arvid Malhotra. 2005. "E-S-Qual: A Multiple - item Scale for Assessing Electronic Service Quality."Journal of Service Research, Volume 7, No. X, Month 2005, page: 1-2. DOI: 10.1177/1094670504271156, Sage Publications.

Prajarta, Nunung. 2010. New Media, HAM, dan Ilmu Komunikasi: Aras dan Arus Perhatian Sosial dan Ilmu Politik Universitas Gadjah Mada.

Perda Kabupaten Sidoarjo Nomor 12 Tahun 2011 tentang Rencana Pembangunan Jangka Menengah Daerah Kabupaten Sidoarjo Tahun 2010-2015.

Purwanto, Erwan Agus.2006. "Pelayanan Publik Partisipatif" dalam Agus Dwiyanto (ed). Mewujudkan Good Governance Melalui Pelayanan Publik. Yogjakarta: GMU Press. Hal.173 222.

Reitz, John C. 2006."E-Government" dalam The American Journal of Comparative Law. Vol.54, American Law in the $21^{\text {st }}$ Century: U.S. National Reports to the XVIIth International Congress of Comparative Law (Fall,2006),pp.733 - 754. Published by: American Society of Comparative 
Stable. URL: http:/ / www.jstor.org. Accesed: 24/05/2010 01:29

Sandyatma, Yudhi Harsatriadi dan Sunarru Samsi Hariadi. 2012. "Partisipasi Anggota Kelompok Tani dalam Menunjang Efektivitas Gapoktan pada Kegiatan Penguatan Lembaga Distribusi Pangan Masyarakat di Kabupaten Bogor" Kawistara. Jurnal Ilmu Sosial dan Humaniora Sekolah Pascasarjana Universitas Gadjah Mada. Volume 2, Nomor 3, 22 Desember 2012, hal. 238 - 251.

Setiawan, Muh. Arif. 2008. "Pembangunan Infrastruktur Perdesaan dengan Partisipasi Masyarakat di Kabupaten Indragiri Hulu." Tesis. Semarang: Undip. Tidak diterbitkan.

Soetomo. 2009. Pembangunan Masyarakat. Yogjakarta: Pustaka Pelajar

Suprawoto. 2007. "Layanan Publik Berbasis E-Government: Studi Kasus KTP Online, PSB Online, dan E-Procurement di Surabaya." Disertasi. Malang: Universitas Brawijaya. Tidak diterbitkan.

Tambouris, E; E. Kalampokis dan K. Tarabanis.2008. "eParticipation Research Project in The European Union: A Survey," International Journal Electronic Business, vol. 6, No. X.

Tashakkori, Abbas \& Charles Tedlie. 1998. Mixed Methodology: Combining Qualitative and Quantitative Approach. London: Sage Publications ltd.

Yulianti. 2006. Partisipasi Masyarakat dalam Perbaikan dan Pemeliharaan Lingkungan Permukiman di Kelurahan Batu Sembilan Kecamatan Tanjungpinang Timur. Tesis. Semarang: Universitas Diponegoro. Tidak diterbitkan.

Zeithaml, V.A. Parasuraman, A, \& Malhotra. 2002. "Service Quality delivery Through Website: a Critical Review of Extant Knowladge". Journal of The Academy of Marketing Science. Vol.30(4), page 362-375 